\title{
A PhD in Social Sciences and Humanities: impacts and mobility to get better salaries in an international comparison.
}

\author{
Giulio Marini, Centre for Global Higher Education (CGHE), Institute of Education UCL \\ g.marini@ucl.ac.uk
}

\begin{abstract}
The paper analyzes which conditions may predict a better salary for people who got a PhD in Social Sciences and Humanities (SS\&H) in 13 European countries. Among the controlling variables, predictors are also: change of country of residence; percentage of time spent respectively in research and managerial activities; and impacts achieved during one's PhD program. Findings, but also policy implications both for PhD program planners and PhD candidates, are: some specific impacts such as having advised policy makers, having released interviews to media and having managed and coordinated projects, all predict better salaries for PhD holders in SS\&H, other things being equal. To move geographically out of one's country where PhD was awarded is also a good predictor of better wages, provided PhD holders don't swap sectors after attainment of PhD.
\end{abstract}

\section{Introduction}

The labour market of $\mathrm{PhD}$ holders has been deemed critical in recent years due to the large number of $\mathrm{PhD}$ holders (Cyranoski et al. 2011). In all disciplines, and basically in all countries, less than half of these educated people can expect to continue a career in academia (van der Weijden, Teelken, de Boer and Dros 2015; Neumann \& Khim Tan 2011), regardless even of tenured permanent or fixed term positions. The subset of the social sciences, and even more the humanities, are more threatened by this phenomenon, as industries might be less frequently interested in hiring personnel with such a high degree from these disciplines (Mangematin 2000; Boosten \& Spithoven 2016). Expectations of employment for PhD holders in academia are also worsening (Eigi 2014; Broadbent \& Strachan 2016) when compared to only one or two decades ago (Enders 2002). For these reasons, questions about the real usefulness and benefit of getting a $\mathrm{PhD}$, especially in SS\&H, have been raised. This doubt increases when considering the long and uncertain path to gain a $\mathrm{PhD}$ in the first place. Any marketable skills and acknowledgment from possible employers are hence critical for both $\mathrm{PhD}$ students on one hand, and institutions awarding PhDs that need to regularly recruit $\mathrm{PhD}$ students (Hermanowicz 2012) on the other hand. Employment in research is no longer considered the only natural path for a $\mathrm{PhD}$ holder. In addition, $\mathrm{PhD}$ holders nowadays risk having an occupation scarcely related to their field of study (Auriol Misu and Freeman 2013).

Given this scenario, the paper examines under which conditions a PhD holder in SS\&H is better off in terms of salary, and aims to identify specific strengths and goals for PhD programs in SS\&H (Halse Mowbray 2011; Evans \& Maresi 2014). These conditions aim at keeping constant the main divide in salary between people working in academia from people working outside academia.

The article is divided in the following way: the next section introduces the main sets of possible predicting factors. Thus, Data and Methodology section provides the variables, their descriptive statistics, and the data analysis design. The following section analyses a general model (model1) to take into account the main factors, plus other models to understand which further conditions may predict a better salary, keeping hold of the key features of this specific labour market (model1). Discussion and conclusion analyse both the scientific findings and the policy suggestions the study offers.

\section{What can make a difference?}

Among several conditions further described in detail later on, three groups of possible determinant factors are discussed: prestige of institutions, mobility and impact. 


\section{Prestige}

Rankings, albeit being widely recognized imperfect ways to measure the quality of an institution (Hazelkorn 2011), have a very strong power in reinforcing and confirming academic prestige, with a manifest feed-forward mechanism (Espeland \& Sauder 2007; Gioia \& Carley 2002). In this regard, it is relevant to empirically test the promises that rankings are implicitly expected to maintain: the higher the ranking of an institution, the higher the chance its students gain a better employment. This factor is particularly interesting as rankings are relatively new in Europe if compared to US (Bedeian et al. 2010). Understanding if and to what extent rankings are actually relevant in providing a critical advantage in the labour market is thus important (Enders 2015). This paper overcomes the restriction of the few international top-ranked European universities (Souto-Otero \& Enders 2015) - an equivalent can be seen for the Russell Group in the UK (Chevalier \& Conlon 2003). The study doesn't only include many countries, but also very differently ranked universities. Moreover, SS\&H are from one side less affected by rankings (Souto-Otero \& Enders 2015), and widely heterogeneous on the other hand: employment of $\mathrm{PhD}$ holders from a business school differs consistently from those from Arts and Humanities (Urbancic 2008; Chen 2007).

\section{Mobility in sectors and in space}

As recent literature affirms (Sutherland 2015), the traditional end market of $\mathrm{PhDs}$ is dominated by highly specialized research. For SS\&H, a labour market external to academia - as it is for engineering or science (Roach \& Sauermann 2010) - is probably more critical. This constitutes also a specific gap in the field when compared to attention given to STEM. Yet, the possibility to drive one's career through possible exits and "coming-back" from other sectors has no literature for SS\&H, as a study is more focused on the process of getting a permanent position out of less secure contracts (Yang and Webber 2015). Content of work (i.e. time spent in several activities) is another orthogonal dimension in relation to sectoral mobility. There can be a trade-off between research and managerial activities: the former can be pursued to some extent also outside academia; the latter are usually seen as a possible evolution over time for PhD holders (Borrell-Damian et al. 2010; Lee, Miozzo and Laredo 2010). Although not exclusively about PhD holders, Oleksiyenko (2013) demonstrates the importance of global mobility and the key role of globally attractive venues, insisting on the dynamic "outbound for upward". For PhD holders, to move in terms of sectors or to change country of residence as a result of having a highly specialized profile is as common as it is volatile (Auriol Misu and Galindo-Rueda 2016; Meissner, Gokhberg and Shmatko 2016) and needs attention and fresh empirical evidence. In general, there is a paucity of literature studying together salary and mobility after the $\mathrm{PhD}$ - being mobility defined as both in geographical and sector terms. This lack of literature is striking in relation to the emergence of boosting numbers of $\mathrm{PhD}$ holders, especially considering the set of SS\&H.

\section{Impacts}

Impacts (and especially the ability to demonstrate them) are of increasing interest in SS\&H (Bastow, Dunleavy Tinkler 2014). Impacts aim especially at measuring the beneficial connections between doing research and designing policies (Boaz, Fitzpatrick Shaw 2009). Nevertheless, impacts are of different kinds and the same concept needs to be disentangled in order to understand what exactly is being measured. Here, impacts are those related to what a PhD program brought to achieve in terms of specific activities, answering the quest of filling the gap in literature about detailed skills a PhD holder in SS\&H might have accrued (Hazelkorn 2015; Platow 2012).

\section{Data and Methodology}

The paper analyzes the payoff of PhD holders in SS\&H attained in 13 European countries (the UK, France, Germany, Spain, Portugal, Switzerland, Italy, Norway, Slovakia, Latvia, Poland, Hungary and Turkey). 2,652 PhD holders have been interviewed with an online questionnaire in 2012 and 2013. National teams getting names from official repositories have collected the sample. Different ways have been used to get 
email contacts or to diffuse the link to the questionnaire (available in all languages of the countries listed). Particular attention was paid to reach PhD holders who might have pursued any mobility in terms of country or sector, which were supposedly less likely to be traced by conventional academic sources (an example is the case of people retrieved via professional social network, where education is typically specified and anonymities can be discarded). This strategy secured a sufficient number of respondents not currently in academic positions, although the academic ones resulted to be slightly oversampled in comparison to OECD figures (see further). The response rate was around 20-25\%. Some variables from the questionnaire are reported on table 2 with the descriptive statistics. A brief discussion follows.

\section{Salary}

The dependent variable is income, normalized by country of residence. Weighting by the index "International Comparative Program" (ICP) released by the World Bank for the year 2012, salaries are rescaled. In this way the real power of purchase of one's salary is taken into account (variable is called "salaryPPP", meaning purchase power parity). In order to better acknowledge the values of around 80 countries of residence, and also to prevent heteroscedasticity in the residuals of regressions, the natural logarithm was used. In particular, often the destination countries of one's current residence represents a return to one's nationality or a move towards a less rich country (according to ICP indexes; 3 over 4 moves towards a richer country among those who move, mostly within Europe - this further detail does not enter analysis as it gave little incremental contribution). Choices are linked by geographical proximity or cultural connections such as languages spoken in former colonies in Latin America or Africa.

\section{Ranking}

From the names - and discipline also when rankings are by disciplines - of the institutions ranking (or scores of ranking) by each responded is computed. The choice of the ranking used is not assumed a priori. “THE World”, “THE Europe”, "THE Social Sciences \& Humanities", "QA" by disciplines, "Webometrics", "ARWU”, "Leiden" and "Leiden Social Sciences" are all computed. The choice of "THE Europe" reflects a preliminary analysis using Pearson correlations (see table 1). In particular, for some of these rankings too many institutions had no rankings (or score) available at all, as some of the countries in the study have few or low ranked institutions falling in ex aequo positions. In fact, the questionnaire has been submitted independently to the quality or prestige of the institutions: although PhDs are not usually given by all the tertiary education institutions in Europe, international rankings often don't cover all the thousands of institutions that exist within Europe. Even if considering "null" or lower ranked those institutions not present in some rankings, the effectiveness of those variables may be poor, probably due to the fact that within unranked universities there are still slightly relevant differences in terms of actual quality. Another important fact is the disciplinary field: the overall standing of the institutions cannot necessarily represent $\mathrm{PhD}$ holders in a specific institution in different disciplines thoroughly. The presence of ranking by disciplines dramatically reduces this possible bias, even though it presents again problems of missing values, causing a trade-off. "THE Europe" and "Webometrics" are those that are able to reduce the missing values. Ultimately, the former was chosen as it has better correlations (and above all more statistically significant correlations) with those rankings informed by disciplines. Table 2 and 3 show only "THE Europe" as the best referral to grasp the prestige of the universities. In particular, "THE Europe" is positively correlated to salary, as it is computed as a "score" (the higher the score, the better the position in the ranking).

>> Table 1 around here $<<$

\section{PhD holders by sector and change of industry}

There are high differences of salaries between the educational system from one side (higher education occupations and other lower educational sectors) and other main sectors of employment (i.e. business, government and NGOs). For this reasons, a dummy variable was created collapsing education from one side $(\mathrm{dSector}=0)$ and not education on the other side $(\mathrm{dSector}=1)$ - being the original question asking for sector of occupation. This variable distinguishes people working in the educational sector on one hand, and all the rest (other public, third sector and charities plus private employers) on the other hand. Some $22 \%$ of 
the respondents don't work in the education sector, whereas the remaining $78 \%$ do work in academia (see table 2, variable "dSector"). People working outside the education sector earn more (positive correlation in table2). A difference in terms of sectoral change after the attainment of one's $\mathrm{PhD}$ was also considered, splitting those who changed and had, at least once, one employer of the other kind (referring to the above mentioned dummy definition). This trace of one's career was possible because the questionnaire was asking up to 4 precedent occupations, apart from the current one. Within the sample, a majority gave information about at least one previous employment. When missing, interviewee has been considered as not having changed sector, as apparently they have the same employer since attainment of PhD. Among the sample, $13.7 \%$ changed sector in their trajectory after the attainment of their $\mathrm{PhD}$ (variable "Change.sector"). On average - although not having statistically significant levels - PhD holders who are "not constant" in the same sector have slightly lower salaries, confirming previous evidence of this sort of mobility in career trajectories (King, Burke \& Pemberton 2005). Both these figures are consistent with recent literature (Auriol, Misu and Freeman 2013; Auriol, Misu and Galindo-Rueda 2016), where, coincidentally, Italy is missing. To this regard a comparison with microdata about only $\mathrm{PhD}$ holders in Italy revealed that this sample overestimates the percentage of people working in any educational sector, as they should represent around two thirds in total. A further check regarding annual average salary controlled by year of attainment and type of employer confirms that this sample is consistent with the main literature (Auriol, Misu and Galindo-Rueda 2016; Auriol, Misu and Freeman 2013), which is relevant to avoid invalidating further analyses.

\section{>> Table 2 around here $<<$}

\section{Gender, years after PhD attainment, age, children and disciplinary background}

On average, $\mathrm{PhD}$ holders in this sample attained the title 4.7 years earlier, with a standard deviation of 2.9. This distribution has a positive skewness. This variable is used as a confounding one, computing the natural logarithm of it ("ln_y" on table 2), such as for age (average of 39 with a S.D. of 7.69 for age and a positive skewness, for actual data). Some $46 \%$ of the interviewees are women. In general, gender pay gap is visible from the correlation. Half of the sample has at least one baby ("Child" variable: $0=$ no child; $1=$ at least one child). To have at least one child does not apparently play a negative role. On the contrary, it has a positive correlation. To have children is not an impediment for earning more among PhD holders possibly due to child planning once employment being better - remaining constant across the gender pay gap. In this sample, 2/3 of PhD holders have a background in Social Science and 30\% in humanities. The sparing $\mathrm{PhD}$ holders made the $\mathrm{PhD}$ in Business Schools, which is a peculiar situation especially when comparing salaries.

\section{Types of work}

A first variable describing the type of work relates to the contract. Contracts have been grouped as "permanent" (variable "contract" $=2 ; 42 \%$ ) and other types (including self-employed workers; variable "contract" $=1 ; 58 \%$ ). This variable makes part of the list of variables in model1 in table 3 . It has a high correlation with salary: 0.3085 .

Another set of questions investigated the content of one's work, regardless of other details such as sector. Time spent in activities related to research ("time_resea") has an average of 38.6\% of the total of one's typical week. Standard deviation for this variable is 27.8 . The other interesting general task (the other three were time spent in "teaching", in "administrative stuff" and "other"; all not considered) is "time spent in managerial tasks" ("time_manag"). The results show that on average people spend $11 \%$ of their time in this latter function, with a standard deviation of 17 . The first of these two variables is negatively correlated to salary, though quite weakly; time spent in management is relatively highly correlated to salary. This variable is interesting as it does not necessarily inform one's sector, as research can be pursued outside academia, although this may follow different percentages and channels in comparison with STEM.

\section{Mobility as changing country of residence}

Mobility refers to the change of country of residence after the attainment of one's $\mathrm{PhD}$ ("ch.country"). This is experienced by $15 \%$ of the interviewees and is in line with larger samples (Auriol Misu and Freeman 
2013; Auriol Misu and Galindo-Rueda 2016). This variable aims at checking whether leaving the country that hosted the $\mathrm{PhD}$ student (also in case the student was from that country originally) may predict a higher salary. The assumption is that coming back to one's country of origin - or exploring further possibilities in a different place from that of $\mathrm{PhD}$ attainment - may be revealed to be a good choice to improve one's salary, at least in comparison with the other PhD holders who didn't move at parity of other conditions. Correlation in this regard is positive. Further more refined variables such as one disentangling by people caming back to his/her home country revealed to be not statistically significant, probably due to few observations available. Other variables regarding mobility during one's $\mathrm{PhD}$ studentship have been tested, resulting in conveying poor or not significant contribution to explain the salary at the moment of interview.

\section{Impacts}

Impact set of questions detects the achievements during the $\mathrm{PhD}$ program. The full wording is "have you ever...": 1) given interviews in media (radio, TV, newspapers) (impct_med); 2) been a board member/volunteer/advisor in an NGO (impct_ngo); 3) developed innovative products (impct_inn); 4) been a board member in a company (impct_cmpny); 6) taught students (impct_teach); 5) participated in societal or political committees (impct_cmmt); 7) advised to policy-actors on the local, regional, national or international level (impct_pol); 8) published textbooks, monographs, articles, books (impt_pub); 9) supervised graduate or PhD students (impct_spvs); 10) managed/coordinated projects (impct_mgmt); 11) taken part in in knowledge transfer activities (impct_kt); 12) participated in policy-relevant conferences or events (impct_cnfr). All variables of this set have 1 for "no" and 2 for "yes". This set of variables is composed by dummies, and so they do not consider the quantity or quality of publications, for instance. They only tell whether each of the activities was done at least once. As shown in table 2, attaining scientific publication is an activity pursued by almost all the $\mathrm{PhD}$ holders (more than 90\%) and is the only one not to have a statistically significant correlation with salary, this being also coherent with findings in the field (Auriol Misu and Freeman 2013). Only this item is dropped from the regression analyses. All the others have positive correlation scores ranging from 0.06 (supervise students) to 0.16 (give interviews to media) or 0.17 (advise policy makers). The Cronbach's alpha for these 12 items is equal to 0.69 , which suggests that in comparison with Platow's (2012) analysis, these items should not be grouped into one summative indicator.

\section{Different Returns for Different Career Trajectories: the Analysis of Common Patterns for PhD Holders in SS\&H}

The present section follows the results showed in Table 3, providing results from OSL regressions in four Models. Breusch-Pagan Tests for each model reject the null hypotheses of heteroscedasticity.

Multicollinearity as well was tested through a variance inflation factor (VIF), resulting in being low enough for all provided models. Table 3 shows both Breusch-Pagan and VIF tests' results.

Model1 is the basic model that explains salary taking into account years elapsed after the $\mathrm{PhD}$, gender combined with having at least one child, ranking score and contractual situation. Macro disciplines (1. Humanities; 2 Social Sciences; 3 Business School), and sector (education vs. other) are also present. Gender and children is a four modes variables computes out of the two binary variable previously discussed. In line with other studies (Morrison, Rudd \& Nerad 2011), paternity does not play an impediment (base is men with no children; "2" is men with children), whereas if compared to men with no children (mode3). Maternity (women with children, mode " 4 ") plays a negative role over earnings. As a result, having children is not always a negative predictor, in contradiction with van Balen et al. (2012), but this is true only for women. Business schools are more likely to guarantee better wages in the labour market, whereas a PhD in social sciences is on its own better than one in the humanities. The basic model also indicates that to work outside academia is better than working in academia. This evidence is coherent with some aspects of recent studies (Sutherland 2015; Boosten \& Spithoven 2016). Variable "contr" informs that being in permanent positions assures better salaries. 
Model 2 adds the dummy variable of changing country of residence after the attainment of a $\mathrm{PhD}$. This variable is positively associated with greater salary at PPP of country of residence, which implies that having the variables of the first model kept constant, to move from the country of study for one's PhD elsewhere improves one's chances of getting a better paid job. Change of sector is also tested and it is not a clear predictor as such. The marginal benefit in mobility by country is around $9 \%$ higher wage, keeping other variables in the model constant. This figure explains the extent to which mobility can have a strong pay off.

Model3 explains that the more a $\mathrm{PhD}$ holder is employed with managerial functions, the higher his/her salary, other things being equal. This finding is interesting as the quantity of time spent on research is not a predictor in one sense or another; but pursuing a managerial role - even keeping constant sector of employment and time elapsed from education attainment - is a good predictor, although this accounts only for an increase of $0.5 \%$ of one's salary.

Model4 tries to understand which impacts from the doctoral activities can predict a better salary after the completion of the doctoral studies. Of the 11 items, only three have statistically significant coefficients. They are "having advised policy makers", "having released interviews to media" and "having managed and coordinated projects" (respectively $2^{\text {nd }}, 8^{\text {th }}$ and $10^{\text {th }}$ items; "impct_med", "impct_pol", "impct_mgmt"). They respectively predict a higher wage of 5.8\%, 7.4\% and 9.5\% if these respective activities were pursued during the PhD. In particular, the latter gives a much higher contribution than the managerial activities led in current job described in Model3. These activities carried out during one's doctoral time are able to predict a better salary, ceteris paribus.

\section{Discussions and Conclusion}

This study finds that while $\mathrm{PhD}$ holders in SS\&H are heterogeneous in terms of employment outcomes, some common patterns may predict better salaries, whereas several points are coherent with recent literature.

Findings can be discussed by prestige, mobility, content of work and impacts. For prestige, the ranking of the institutions that awarded the $\mathrm{PhD}$ plays a small role in determining the $\mathrm{PhD}$ holder's future, in coherence with another survey (Souto-Otero \& Enders 2015). Regarding mobility, some more insights are provided about the problem of employment destiny of PhD holders nowadays. Borjas (2006) in the US faced the problem of inflation of $\mathrm{PhD}$ holders softening the market, especially in the case of post docs in science. This study looks at a possible positive angle by highlighting that to change country of residence has a positive pay-off in terms of employment (at least looking at salaries at PPP). In this regard, findings are not in contradiction with the literature and are encouraging for more research on the theme of mobility, mapping even more in detail the places and conditions which allow to have this "outbound to upward" effect. On the contrary, this evidence suggests that a $\mathrm{PhD}$ is somehow a sort of hyper-specializing title that can be better spent in a global labour market when some transversal or transferable skills are empowered amidst traditional hyper-specialization activities (Meissner Gokhberg and Shmatko 2016). Nevertheless, it is also to be specified that it is possible that "movers" and "stayers" differ in unobservable characteristics that the present study does not look at, such as social capital to get highly rewarded and specific positions overseas. All in all, mobility in space and in economic sector for SS\&H are not so different from people with a background in IT (King, Burke, Pemberton 2005). To look for opportunities abroad (one's country of origin included if the $\mathrm{PhD}$ was done in a different country from one's nationality, but not exclusively), especially working outside academia, appears to predict better career outcomes, at least in terms of salary.

In other words, the idea that $\mathrm{PhD}$ holders are specialists in making research is confirmed to be reductive. To spend more time during one's typical week "doing research" in comparison with "managing" (Model3), we see that - for the sake of having a better paid job - it is slightly a better thing to be employed primarily as a manager rather than as primarily as researcher. This evidence highlights the point that even though it is not possible from this data to compare equivalent graduates with $\mathrm{PhD}$ holders both in $\mathrm{SS} \& \mathrm{H}$, among the latter, to have applied and gained a position requiring managerial activities is a good predictor of success. The content of one's work matters and even though this study can't speak about the degree of better chances for $\mathrm{PhD}$ holders to get a managerial job in comparison with graduates (Christiansen Schröter 
Joensen, and Skyt Nielsen 2007), it suggests PhD holders should consider this, at least if they are moneyoriented. It is also worth of note that $\mathrm{PhD}$ holders are resilient in their choices of sector destination (Bloch et al. 2015). Hence, the point that the paper proposes is the following: whether a PhD-holders in SS\&H will try to continue to work in academia or not, salary is better under certain conditions such as those regarding called "impact", which is coherent even for PhD holders remaining in academia (Waaijer 2017).

In fact, impact is perhaps the most interesting topic for discussion together with mobility by country. This contribution does not address the issue of usefulness of getting a PhD in SS\&H for society or its potential in impacting the economy as such. It is assumed that both phenomena exist and that it is reasonable to believe that nowadays $\mathrm{PhD}$ holders inside or outside academia are contributing overall to a better society anyway (Smith 2010). In addition, the paper investigates through the most difficult and heterogeneous group of PhDs, those in $\mathrm{SS} \& \mathrm{H}$, what may influence a higher salary, overcoming generic assumptions of beneficial outcomes for the community on one hand, and individuating specific factors of personal success on the other hand. By analyzing which "impact really impact" over salary, it is possible to give substance to general questions raised by Halse and Mowbray (2011), and also to overcome a generic assumption starting that $\mathrm{PhD}$ holders in general have "better problem-solving skills" (Lee at al. 2010). Some "impacts", then, are transversal to all sorts of employment conditions, but not all of them. To be able to be managers, to communicate outside one's scientific community, and to be able to give policy advice all pay off.

In general, the study also informs individual agency for people committed to building one's employment as an occasion of incessant knowledge acquisition (McAlpine \& Emmioğlu 2015) in a growing context of hybridism professionalism (Noordegraaf 2007), which supposedly hampers some domains of the SS\&H. In other words, the necessity of a balanced human resources management for talented workers (Thunnissen, Boselie, \& Fruytier 2013) is checked from the preferences employers manifested via salary differences, also keeping constant the expected general delta between the educational sector and other types of employers. It is possible to see what society rewards more from what $\mathrm{PhD}$ holders have to offer, with several conditions kept constant. Moreover, these findings are more relevant because potentially all the factors illustrated can be devised by universities even without resorting to $\mathrm{PhD}$ programs connected to the industrial world, as this is more difficult for SS\&H (Borrell-Damian et al. 2010; Malfroy 2011). Many of the positive predictors, on the contrary, are already part of widespread claims by funding agencies just under the dictation of "impacts", with probably the UK being the clearest of the examples in the European context.

In fact, policy oriented findings for universities are also derived. The study may inform the PhD programs aimed at attracting more candidates in the plural fields of SS\&H, as PhD holders after their experience perform slightly differently according to some specific "impact" that might have elevated their profiles. What $\mathrm{PhD}$ students achieve during their experience as $\mathrm{PhD}$ candidates is not neutral of consequences for their future earnings. In contrast to Lightowler and Knight (2013), it can be argued here that the role of connecting SS\&H and the external world is not necessarily a task to be done by specific "knowledge brokers". To integrate or to combine the very specific domain of one's $\mathrm{PhD}$ experience with these "impacts" is a key point. It is not a matter of having some specialisms; it appears more a matter of diffusing the awareness among $\mathrm{PhD}$ students (and their supervisors) that some transversal competencies are relevant in contracting a better portfolio for one's future employment, regardless of the type of career one will have as a $\mathrm{PhD}$ holder in the future. This finding does not contradict other studies with regard to PhD learning conditions (Lindén 2013; Manathunga, Pitt \& Critchley 2009; Mowbray \& Halse 2010). On the contrary, it gives practical and more specific indications, potentially for all types of $\mathrm{PhD}$ programs nowadays supplied by European universities (Kehm \& Teichler 2016). This fact is also important when devising possible $\mathrm{PhD}$ programs in order to show that candidates may learn something more useful in so far as it appears to be more marketable. Interestingly, this latter point is stronger even in comparison to an a posteriori opinion such as "the beneficial impact for one's career". In part this can be explained by the fact that a beneficial effect for one's career is apparent also for many PhD holders who are working in academia, and especially for those committed to research. In that case to have pursued a $\mathrm{PhD}$ was basically an essential step, whereas here a $\mathrm{PhD}$ is found to convey positive marginal advantages also for other $\mathrm{PhD}$ holders working outside educational sectors.

All in all, it appears that having a $\mathrm{PhD}$ in $\mathrm{SS} \& \mathrm{H}$ is not a situation you may group together if you look at averages of salaries, but some common patterns are visible. Except for the expected results shown in 
Model1 that substantially confirms previous studies, findings from the other Models arguably demonstrate that there is room to have different developments during the $\mathrm{PhD}$ that can generate advantages, filling a gap already identified (Halse \& Mowbray 2011) and giving more specific substance to general perspectives for PhD holders (Meissner, Gokhberg and Shmatko 2016). PhD programs on one hand (i.e. offering more opportunities to make $\mathrm{PhD}$ "impact" on the external world), and personal choices on the other hand (i.e. being open minded in changing country of residence and committing oneself also in not strictly research-laden activities), can be optimized to achieve better employment conditions - provided that the unfettered interest in undertaking a $\mathrm{PhD}$ in se remains a legitimate individual motivation and also a vital and fundamental societal justification.

\section{References}

Auriol, L., M. Misu and R. A. Freeman. 2013. "Careers of Doctorate Holders: Analysis of Labour Market and Mobility Indicators.” OECD Science, Technology and Industry Working Papers, 2013/04, OECD Publishing.

$10.1787 / 5 \mathrm{k} 43 \mathrm{nxgs} 289 \mathrm{w}-\mathrm{en}$.

Auriol L., Misu T., Galindo-Rueda F. 2016. "Doctorate Holders' Labor Market and Mobility: The Academic Career as the First Choice.” In The Science and Technology Labor Force. The Value of Doctorate Holders and Development of Professional Careers edited by Gokhberg, L., Shmatko, N. Auriol, L., 51-75. Dordrecht: Springer.

Bastow S., Patrick Dunleavy P., Jane Tinkler J. (2014) The Impact of the Social Sciences: How Academics and their Research Make a Difference, Sage: London.

Bedeian A.G., Cavazos D.E., Hunt J.G., Jauch L. R. 2010. Doctoral Degree Prestige and the Academic Marketplace: A Study of Career Mobility Within the Management Discipline. Academy of Management Learning \& Education, 9 (1), 11-25. http://www.jstor.org/stable/25682430

Bloch C., E.K. Graversen, H. S. Pedersen. 2015. "Researcher mobility and sector career choices among doctorate holders." Research Evaluation 24: 171-180 https://doi.org/10.1093/reseval/rvv004.

Boaz A., S. Fitzpatrick, B. Shaw. 2009. “Assessing the impact of research on policy: A literature review.” Science and Public Policy 36 (4): 255-270. 10.3152/030234209X436545

Boosten K., and A. Spithoven .2016. "Pecuniary and Scientific Motives as Drivers of PhD Careers: Exploring the Evidence from Belgium." In The Science and Technology Labor Force. The Value of Doctorate Holders and Development of Professional Careers edited by Gokhberg, L., Shmatko, N. Auriol, L., 121-144. Dordrecht: Springer.

Borjas G. J. (2006) Immigration in high-skill labor markets: the impact of foreign students on the earnings of the doctorates. NBER WORKING PAPER SERIES, Working Paper 12085. https://papers.ssrn.com/sol3/papers.cfm?abstract id=888287

Borrell-Damian L., T. Brownb, A. Dearingc, J. Fontd, S. Hagene, J. Metcalfef, J. Smith. 2010. "Collaborative Doctoral Education: University-Industry Partnerships for Enhancing Knowledge Exchange.” Higher Education Policy 23: $493-514$. 10.1057/hep.2010.20.

Broadbent K. and G. Strachan. 2016. “'It's difficult to forecast your longer term career milestone': career development and insecure employment for research academics in Australian universities." Labour \& Industry: a journal of the social and economic relations of work. 10.1080/10301763.2016.1243438.

Chen, L. H. 2007. “Choosing Canadian Graduate Schools from Afar: East Asian Students' Perspectives.” Higher Education 54 (5): 759-80. 10.1007/s10734-006-9022-8

Chevalier, A., and G. Conlon. 2003. "Does It Pay to Attend a Prestigious University?” IZA Discussion Paper No. 848. Available at SSRN: https://ssrn.com/abstract $=435300$

Christiansen C., J. Schröter Joensen, H. Skyt Nielsen. 2007. "The risk-return trade-off in human capital investment.” Labour Economics 14: 971-986. 10.1016/j.labeco.2007.06.001.

Cyranoski D., N. Gilbert, H. Ledford, A. Nayar, M. Yahia. 2011. "Education: The PhD factory. The world is producing more PhDs than ever before. Is it time to stop?” Nature 472: 276-279. 10.1038/472276a.

Eigi J., P. Põiklik, E. Lõhkivi, K. Velbaum. 2014. "Supervision and Early Career Work Experiences of Estonian Humanities Researchers Under the Conditions of Project-based Funding." Higher Education Policy, 27 (4): 453-468. 10.1057/hep.2014.21.

Enders, J. 2015. "The Academic Arms Race. International Rankings and Global Competition for World-Class Universities." In The Institutional Development of Business Schools, edited by A. W. Pettigrew, E. Cornuel, and U. Hommel, $155-175$. Oxford: Oxford University Press.

Enders J. 2002. "Serving many masters: The PhD on the labour market, the everlasting need of inequality, and the premature death of Humboldt." Higher Education 44: 493-517. 10.1023/A:1019850524330 
Espeland, W.N. and M. Sauder. 2007. "Rankings and Reactivity: How Public Measures Recreate Social Worlds.” American Journal of Sociology 113 (1): 1-40. 10.1086/517897

Evans B., and N. Maresi Eds. 2014. Globalization and its impacts on the quality of PhD education. Rotterdam: Sense.

Gioia, D. and K.G. Corley. 2002. "Being Good versus Looking Good: Business School Rankings and the Circean Transformation from Substance to Image.” Academy of Management Learning and Education, 1: $107-121$. 10.5465/AMLE.2002.7373729.

Hazelkorn E. 2011. Rankings and the Reshaping of Higher Education. The Battle for World-Class Excellence. Basingstoke: Palgrave.

Hazelkorn E. 2015. "Making an impact: New directions for arts and humanities research." Arts and Humanities in Higher Education February 14 (1): 25-44. 10.1177/1474022214533891.

Halse C., and S. Mowbray. 2011. “The impact of the doctorate.” Studies in Higher Education 36 (5): 513-525. 10.1080/03075079.2011.594590.

Hermanowicz J. 2012. "The Sociology of Academic Careers: Problems and Prospects.” In Higher Education: Handbook of Theory and Research edited by Smart J. C., Michael B. Paulsen M.B., 207-248. Dordrecht: Springer.

Kehm B.M., Teichler U. 2016. "Doctoral Education and Labor Market: Policy Questions and Data Needs." In The Science and Technology Labor Force: The Value of Doctorate Holders and Development of Professional Careers edited by Gokhberg, L., Shmatko, N. Auriol L. 11-30. Dordrecht: Springer.

King Z., S. Burke, J. Pemberton. 2005. “The 'bounded' career: An empirical study of human capital, career mobility and employment outcomes in a mediated labour market.” Human Relations 58 (8): 981-1007. 10.1177/0018726705058500

Lee H., M. Miozzo, P. Laredo. 2010. "Career patterns and competences of PhDs in science and engineering in the knowledge economy: The case of graduates from a UK research-based university." Research Policy 39: 869-881. 10.1016/j.respol.2010.05.001

Lightowler, C., and C. Knight. 2013. "Sustaining knowledge exchange and research impact in the social sciences and humanities: investing in knowledge broker roles in UK universities." Evidence \& Policy: A Journal of Research, Debate and Practice 9 (3): 317-334. 10.1332/174426413X662644.

Lindén J., M. Ohlin, E.M. Brodin. 2013. "Mentorship, supervision and learning experience in PhD education." Studies in Higher Education 38 (5): 639-662. 10.1080/03075079.2011.596526.

Malfroy J. 2011. "The impact of university-industry research on doctoral programs and practices.” Studies in Higher Education 36 (5): 571-584. 10.1080/03075079.2011.594594.

Manathunga C., R. Pitt, C. Critchley. 2009. "Graduate attribute development and employment outcomes: tracking PhD graduates.” Assessment \& Evaluation in Higher Education 34 (1): 91-103. 10.1080/02602930801955945.

Mangematin, V. 2000. "PhD job market: Professional trajectories and incentives during the PhD." Research Policy 29: 74156. 10.1016/S0048-7333(99)00047-5.

McAlpine L. and E. Emmioğlu. 2015. Navigating careers: The perceptions of sciences doctoral students, post-PhD researchers, and pre-tenure academics. Studies in Higher Education 40 (10): 1770-1785 10.1080/03075079.2014.914908.

Meissner, D., Gokhberg, L., Shmatko N. (2016) The Meaning of Doctorate Holders for Human Capital Development of Nations. In The Science and Technology Labor Force. The Value of Doctorate Holders and Development of Professional Careers edited by Gokhberg, L., Shmatko, N. Auriol L. 343-350. Dordrecht: Springer.

Morrison E., E. Rudd, M. Nerad 2011. “Onto, Up, Off the Academic Faculty Ladder: The Gendered Effects of Family on Career Transitions for a Cohort of Social Science Ph.D.s.” The Review of Higher Education 34 (4): 525-553. http://muse.jhu.edu/article/439956

Mowbray S. and C. Halse. 2010. "The purpose of the PhD: theorising the skills acquired by students." Higher Education Research \& Development 29 (6) 653-664. 10.1080/07294360.2010.487199.

Neumann R., and K. Tan. 2011. "From PhD to initial employment: the doctorate in a knowledge economy." Studies in Higher Education, 36 (5): 601-614. 10.1080/03075079.2011.594596.

Noordegraaf, M. (2007) "From "Pure" to "Hybrid" Professionalism Present-Day Professionalism in Ambiguous Public Domains." Administration and Society 39 (6): 761-785. 10.1177/0095399707304434.

Oleksiyenko A. 2013. Opportunity structures and higher learning in a globally-connected place: tensions and ties between outbound and upward mobility. Higher Education 66: 341-356.

Platow, M. J. 2012. "PhD experience and subsequent outcomes: a look at self-perceptions of acquired graduate attributes and supervisor support.” Studies in Higher Education 37 (1) 103-118. 10.1080/03075079.2010.501104.

Roach, M. and H. Sauermannb. 2010. A taste for science? PhD scientists' academic orientation and self-selection into research careers in industry. Research Policy 39 422-434. 10.1016/j.respol.2010.01.004. 
Smith, A. 2010. One step beyond: Making the most of postgraduate education. Report for UK. Department for Business, Innovation and Skills. http://www.bis.gov.uk/postgraduatereview.

Souto-Otero M., and J. Enders. 2015. "International students' and employers' use of rankings: a cross-national analysis." Studies in Higher Education 783-810. DOI: 10.1080/03075079.2015.1074672

Sutherland K.A. 2015. "Constructions of success in academia: an early career perspective." Studies in Higher Education 743-759. 10.1080/03075079.2015.1072150.

Thunnissen, M., P. Boselie B. Fruytier. 2013. "Talent management and the relevance of context: Towards a pluralistic approach.” Human Resource Management Review 23 (4): 326-336. doi:10.1016/j.hrmr.2013.05.004.

Urbancic F.R. 2008. “A Multiattributes Approach for Ranking PhD Programs.” Journal of Education for Business 83 (6): 339-346. 10.3200/JOEB.83.6.339-346.

van Balen B., P. van Arensbergen, I. van der Weijden, P. van den Besselaar. 2012. "Determinants of Success in Academic Careers.” Higher Education Policy 25 (3): 313-334. 10.1057/hep.2012.14.

van der Weijden I., C. Teelken, M. de Boer, M. Dros. 2015. "Career satisfaction of postdoctoral researchers in relation to their expectations for the future." Higher Education 72 (1): 25-40. DOI:10.1007/s10734-015-9936-0.

Waaijer C. 2017. Perceived career prospects and their influence on the sector of employment of recent PhD graduates, Science and Public Policy, 44 (1): 1-12. 10.1093/scipol/scw007.

Yang L. and Webber K. 2015. "A decade beyond the doctorate: the influence of a US postdoctoral appointment on faculty career, productivity, and salary." Higher Education 70: 667-687. DOI 10.1007/s10734-015-9860-3 
Table 1. Matrix correlations between different Rankings with statistical significance. Flagged [*] ranking are set as "scores", other are row positions in the rankings.

\begin{tabular}{|c|c|c|c|c|c|c|c|c|c|}
\hline & & 1 & 2 & 3 & 4 & 5 & 6 & 7 & 8 \\
\hline$[$ * ] THEeurope & (1) | & 1.0000 & & & & & & & \\
\hline & । & & & & & & & & \\
\hline \multirow[t]{2}{*}{ WEBOMETRICS } & (2) I & -0.2706 & 1.0000 & & & & & & \\
\hline & । & 0.0000 & & & & & & & \\
\hline THE_world & । & 0.0000 & 0.0000 & & & & & & \\
\hline \multirow[t]{2}{*}{ Leiden } & (4) | & 0.7349 & -0.4628 & -0.7914 & 1.0000 & & & & \\
\hline & । & 0.0000 & 0.0000 & 0.0000 & & & & & \\
\hline ARWU & $(5) \mid$ & 0.6885 & -0.6923 & -0.6880 & 0.5383 & 1.0000 & & & \\
\hline Leidenss & I & 0.0000 & 0.9848 & 0.0000 & 0.0000 & 0.0000 & & & \\
\hline \multirow[t]{2}{*}{ QS_disciplins } & $(7) \mid$ & -0.5966 & 0.0562 & 0.6814 & -0.3283 & -0.4363 & 0.0326 & 1.0000 & \\
\hline & । & 0.0000 & 0.1404 & 0.0000 & 0.0000 & 0.0000 & 0.4331 & & \\
\hline \multirow[t]{2}{*}{ THE_SSH } & $(8) \mid$ & -0.6271 & 0.0365 & 0.6288 & -0.5453 & -0.2847 & -0.5221 & 0.2696 & 1.0000 \\
\hline & । & 0.0000 & 0.5112 & 0.0000 & 0.0000 & 0.0000 & 0.0000 & 0.0000 & \\
\hline
\end{tabular}


Table 2. Descriptive statistics of variables and Pearson correlation to salary at PPP levels and respective natural logarithm.

\begin{tabular}{|c|c|c|c|c|c|c|c|c|c|}
\hline Variable & Obs & Mean & Std. Dev. & Min & Max & SalaryPPP & $p$ & In_salaryPPP & $p$ \\
\hline salaryPPP & 2,435 & 22.34773 & 17.67097 & 0 & 297.63 & 1.0000 & 0.0000 & 1.0000 & 0.0000 \\
\hline ln_y & 2,426 & 1.316291 & 0.7239166 & 0 & 2.485 & 0.2037 & 0.0000 & 0.2452 & 0.0000 \\
\hline Age & 2,600 & 38.84385 & 7.691848 & 25 & 75 & 0.1718 & 0.0000 & 0.2200 & 0.0000 \\
\hline Sex & 2,608 & 0.4616564 & 0.4986232 & 0 & 1 & 0.1403 & 0.0000 & 0.1942 & 0.0000 \\
\hline Child & 2,633 & 0.5028485 & 0.5000869 & 0 & 1 & 0.1486 & 0.0000 & 0.1766 & 0.0000 \\
\hline THEeurope & 2,560 & 38.07617 & 58.44494 & 0 & 200 & 0.1401 & 0.0000 & 0.1835 & 0.0000 \\
\hline Contr & 2,532 & 1.422986 & 0.4941308 & 1 & 2 & 0.1946 & 0.0000 & 0.2795 & 0.0000 \\
\hline Disc.H. & 2,567 & 0.3139852 & 0.4642009 & 0 & 1 & -0.1201 & 0.0000 & -0.1603 & 0.0000 \\
\hline Disc.SS & 2,567 & 0.6712115 & 0.4698645 & 0 & 1 & 0.1006 & 0.0000 & 0.1395 & 0.0000 \\
\hline Disc.Bus.Sch. & 2,567 & 0.0148033 & 0.1207883 & 0 & 1 & 0.0697 & 0.0007 & 0.0706 & 0.0008 \\
\hline dSector & 2,532 & 0.2207741 & 0.4148504 & 0 & 1 & 0.2336 & 0.0000 & 0.1870 & 0.0000 \\
\hline Change_sector & 2,545 & 0.1371316 & 0.3440539 & 0 & 1 & -0.0081 & 0.6947 & 0.0174 & 0.4083 \\
\hline changecountry & 2,542 & 0.1479150 & 0.3550856 & 0 & 1 & 0.1717 & 0.0000 & 0.1340 & 0.0000 \\
\hline time_resea & 2,516 & 38.64626 & 27.84022 & 0 & 100 & -0.1605 & 0.0000 & -0.1629 & 0.0000 \\
\hline time_manag & 2,516 & 10.92488 & 17.24921 & 0 & 100 & 0.2405 & 0.0000 & 0.2400 & 0.0000 \\
\hline impct_med & 2,532 & 1.498815 & 0.5000974 & 1 & 2 & 0.1773 & 0.0000 & 0.1898 & 0.0000 \\
\hline impct_ngo & 2,487 & 1.242863 & 0.4288991 & 1 & 2 & 0.0886 & 0.0000 & 0.0880 & 0.0000 \\
\hline impct_innv & 2,478 & 1.225182 & 0.4177862 & 1 & 2 & 0.1273 & 0.0000 & 0.1148 & 0.0000 \\
\hline impct_cmpny & 2,454 & 1.101874 & 0.3025448 & 1 & 2 & 0.1642 & 0.0000 & 0.1400 & 0.0000 \\
\hline impct_teach & 2,624 & 1.892912 & 0.3092846 & 1 & 2 & 0.0635 & 0.0018 & 0.0435 & 0.0372 \\
\hline impct_cmmt & 2,509 & 1.342367 & 0.4745964 & 1 & 2 & 0.0860 & 0.0000 & 0.0919 & 0.0000 \\
\hline impct_pol & 2,490 & 1.368273 & 0.4824329 & 1 & 2 & 0.1860 & 0.0000 & 0.2245 & 0.0000 \\
\hline impct_pub & 2,630 & 1.917871 & 0.2746138 & 1 & 2 & 0.0217 & 0.2870 & 0.0098 & 0.6372 \\
\hline impct_spvs & 2,564 & 1.693838 & 0.4609879 & 1 & 2 & 0.0607 & 0.0032 & 0.0504 & 0.0168 \\
\hline impct_mgmt & 2,538 & 1.627266 & 0.4836276 & 1 & 2 & 0.2004 & 0.0000 & 0.2237 & 0.0000 \\
\hline impct_kt & 2,535 & 1.645365 & 0.4784970 & 1 & 2 & 0.0846 & 0.0000 & 0.0727 & 0.0006 \\
\hline impct_cnfr & 2,537 & 1.635396 & 0.4814138 & 1 & 2 & 0.1182 & 0.0000 & 0.1446 & 0.0000 \\
\hline
\end{tabular}

For "Sector": "0" is education; " 1 " is other sector

For "contr": "2" permanent positions; " 1 " is other forms of contract

For "impct_*" variables: "1" is "No"; "2" is "Yes" 
Table 3. 5 Models to predict Salary at PPP (In corrected).

\begin{tabular}{|c|c|c|c|c|}
\hline & M1 & M2 & M3 & M4 \\
\hline \multirow[t]{2}{*}{$\ln \_\mathrm{y}$} & 0.117 & 0.118 & 0.113 & 0.088 \\
\hline & $(7.06) * *$ & $(6.93)^{* *}$ & $(6.88)^{* *}$ & $(4.90)^{* *}$ \\
\hline \multirow[t]{2}{*}{ ln_age } & 0.249 & 0.256 & 0.226 & 0.258 \\
\hline & $(3.43) * *$ & $(3.47)^{* *}$ & $(3.11)^{* *}$ & $(3.23)^{* *}$ \\
\hline \multirow[t]{2}{*}{ 2bn.sex_child2 } & 0.212 & 0.204 & 0.199 & 0.176 \\
\hline & $(6.33)^{* *}$ & $(6.01)^{* *}$ & $(6.01)^{* *}$ & $(4.98)^{* *}$ \\
\hline \multirow{2}{*}{ 3.sex_child2 } & -0.029 & -0.041 & -0.03 & -0.022 \\
\hline & -0.9 & -1.26 & -0.93 & -0.64 \\
\hline \multirow{2}{*}{ 4.sex_child2 } & -0.072 & -0.076 & -0.07 & -0.073 \\
\hline & $(2.21)^{*}$ & $(2.33) *$ & $(2.17)^{*}$ & $(2.15)^{*}$ \\
\hline \multirow{2}{*}{ 2bn.disc } & 0.179 & 0.185 & 0.172 & 0.164 \\
\hline & $(7.56) * *$ & $(7.76)^{* *}$ & $(7.35)^{* *}$ & $(6.36)^{* *}$ \\
\hline \multirow{2}{*}{ 3.disc } & 0.514 & 0.532 & 0.497 & 0.479 \\
\hline & $(3.32) * *$ & $(3.44)^{* *}$ & $(3.25)^{* *}$ & $(3.11)^{* *}$ \\
\hline \multirow[t]{2}{*}{ THEeurope } & 0.001 & 0.001 & 0.001 & 0.001 \\
\hline & $(5.81)^{* *}$ & $(4.51)^{* *}$ & $(5.89)^{* *}$ & $(5.20)^{* *}$ \\
\hline \multirow[t]{2}{*}{ dSector } & 0.216 & 0.218 & 0.157 & 0.224 \\
\hline & $(7.75)^{* *}$ & $(7.64)^{* *}$ & $(5.36)^{* *}$ & $(7.29)^{* *}$ \\
\hline \multirow[t]{2}{*}{ contr } & 0.182 & 0.188 & 0.158 & 0.172 \\
\hline & $(7.81)^{* *}$ & $(7.95)^{* *}$ & $(6.68)^{* *}$ & $(6.96)^{* *}$ \\
\hline \multirow[t]{2}{*}{ changecountry } & & 0.091 & & \\
\hline & & $(2.72)^{* *}$ & & \\
\hline \multirow[t]{2}{*}{ change_sector } & & -0.023 & & \\
\hline & & -0.7 & & \\
\hline \multirow[t]{2}{*}{ time_research } & & & 0 & \\
\hline & & & -0.59 & \\
\hline \multirow[t]{2}{*}{ time_manag } & & & 0.005 & \\
\hline & & & $(6.54)^{* *}$ & \\
\hline \multirow[t]{2}{*}{ impct_cnfr } & & & & -0.012 \\
\hline & & & & -0.44 \\
\hline \multirow[t]{2}{*}{ impct_med } & & & & 0.058 \\
\hline & & & & $(2.28)^{*}$ \\
\hline \multirow[t]{2}{*}{ impct_ngo } & & & & -0.023 \\
\hline & & & & -0.81 \\
\hline \multirow[t]{2}{*}{ impct_innv } & & & & 0.04 \\
\hline & & & & -1.4 \\
\hline impct_cmpny & & & & 0.073 \\
\hline & & & & -1.77 \\
\hline impct_teach & & & & 0.061 \\
\hline & & & & -1.34 \\
\hline impct_cmmt & & & & -0.014 \\
\hline & & & & -0.54 \\
\hline impct_pol & & & & 0.074 \\
\hline & & & & $(2.70)^{* *}$ \\
\hline impct_spvs & & & & 0.016 \\
\hline & & & & -0.57 \\
\hline impct_mgmt & & & & 0.095 \\
\hline & & & & $(3.65)^{* *}$ \\
\hline impct_kt & & & & -0.013 \\
\hline & & & & -0.52 \\
\hline _cons & 1.445 & 1.407 & 1.546 & 0.948 \\
\hline & $(5.74) * *$ & $(5.48)^{* *}$ & $(5.98)^{* *}$ & $(3.26) * *$ \\
\hline$R^{2}$ & 0.24 & 0.25 & 0.26 & 0.27 \\
\hline$N$ & 1,934 & 1,892 & 1,932 & 1,705 \\
\hline Breusch-Pagan Test's F & 0.0000 & 0.0000 & 0.0000 & 0.0000 \\
\hline VIF score & 1.32 & 1.30 & 1.33 & 1.28 \\
\hline
\end{tabular}

